\title{
静圧頭を利用する逆漫透法塩水脱塩システム に及ぼす溶質透過の影響
}

\author{
宮武 修・田川公太朗
}

九州大学大学院工学研究科 化学システム工学専攻, 812-8581 福岡市東区箱崎 6-10-1

\begin{abstract}
深海の静圧頭を利用する逆漫透法海水淡水化システムに関する前報の数値解析を補完するため, 膜の溶 質透過を考虑し，立て坑内塩水の静圧頭を利用する逆漫透法塩水脱塩システムの数值解析を行った。管型 逆漫透膜と丸棒の間に形成される幅の適度に狭い環状流路内で, 濃度差に基づいて誘起される層流自然対 流場の速度, 濐度, および圧力の軸方向変化, ならびに淡水透過速度および透過淡水濃度の軸方向変化に 及ぼす流路長さ, 懸垂深さ, 純水透過係数, 溶質透過係数, およびシュミット数の影響に関する数值解析 結果を得た。光の結果から, 懸垂深さおよび純水透過係数を大きくすることは, 取得淡水量の增大と取得 淡水漕度の低下をもたらすことを定量的に示した。
\end{abstract}

\section{緒言}

海水の静圧頭が通常海水の浸透圧の 2 倍程度になる海面下 500 $\mathrm{m}$ に，両端が解放状態の管型逆浸透膜を垂直に組み込んだ容器を 沈めると，逆浸透膜を通して淡水が得られる。この際，管内で濃 縮された海水は濃度差に基づく自然対流によって管下端から流出 し，管上端から流入する周囲海水と連続的に置換される．海中で 容器にかかる浮力と容器の重さを釣り合わせておけば, 取得淡水 分の重量をリールで巻き上げるだけで, 電力を要することなく飲 料水が確保できるので, 海難漂流時に対処することが可能となる. また, 深海の低温 - 恒温 - 高圧 - 静寂環境の利用や海底鉱物資源 の開発を行うための有人深海ステーション(Kaiyoshuppan, 1991)への給水も可能となる. さらに, 取得淡水は $2.7 \mathrm{~kW} \cdot \mathrm{h} / \mathrm{m}^{3}$ の消費電力で海上に汲み上げることができるので, 高圧ポンプを 用いる陸上用逆浸透法海水淡水化の消費電力 $6 \sim 7 \mathrm{~kW} \cdot \mathrm{h} / \mathrm{m}^{3}$ に 比べ，かなりの省エネルギー化が図れる。

静圧頭を駆動源とする自然対流場においては, 高圧ポンプを駆 動源とする強制対流場とは異なり, 逆浸透膜近傍で生ずる濃度分 極によって淡水透過駆動圧力差がより低下し, 取得淡水量の減少 を引き起こすことが懸念されるので, 管型逆浸透膜中心軸に丸棒 を挿入することにより自然対流量を増大させることを考え, 前報 (Miyatake et al., 1997) では, 溶質透過が無視できる塩除去率の 高い膜（通常，99.4～99.7\%）を用いた場合について, 海水淡水 化システムの諸特性に関する数值解析を行った.

その後, 新設の立て坑内や水没した石炭鉱山の立て坑内に逆浸 透膜モジュールを懸垂させ, 導入した海水や通常海水の 1/16 1/ 14 と低い塩分濃度の滞水を脱塩することが検討されるようにな った (Hayashi, 1997 ; Water Re-use Promotion Center, 1997). この場合，必ずしも塩除去率の高い膜を使用する必要はない。ま た, 用途面 (ビル・工場の廃水処理, 食品工業の溶液処理, 等) から, 現時点で製造されている管型逆浸透膜の塩除去率はあまり 高くなく，本システムの実証試験を行うには，その膜を用いなけ ればならない制約がある.

このような背景から, 本報では静圧頭を利用する逆浸透法塩水

† 1998 年 8 月 3 日受理

†† miyatake@chem-eng.kyushu-u.ac.jp
脱塩システムの諸特性に及ぼす溶質透過の影響に関する数值解析 を行い, 透過淡水の塩分濃度および流量に及ぼす種々の因子の影 響を究明し, 装置の最適設計に寄与する知見を提出する.

\section{1. 基礎方程式，境界条件，および巨視的物質収支式}

前報（Miyatake et al., 1997） と同様, 管型逆浸透膜面内径と 丸棒外径の間に形成される環状流路の間隔は適度に狭く（内径· 外径比 $0.4 \sim 1.0$ ), 平行平板間流路で近似できるものとする.

解析系および座標系を Fig. 1 に示す. 長さ $l$ の平行平板が距離 $b$ を隔てて垂直に設置されており, 片方は純水および幾分かの溶 質を透過する逆浸透膜面，他方は非透過性面である.

浮力の項に関する塩水密度以外の物性值を一定と仮定すると, 流路内における連続の式, 運動方程式, および物質拡散方程式は,

$$
\begin{aligned}
& \frac{\partial u}{\partial x}+\frac{\partial v}{\partial y}=0 \\
& u \frac{\partial u}{\partial x}+v \frac{\partial u}{\partial y}=-\frac{1}{\rho} \frac{d\left(p-p_{0}\right)}{d x}+\nu \frac{\partial^{2} u}{\partial y^{2}}+\gamma g\left(c-c_{0}\right) \\
& u \frac{\partial c}{\partial x}+v \frac{\partial c}{\partial y}=D \frac{\partial^{2} c}{\partial y^{2}}
\end{aligned}
$$

ここで, $u, v$ はそれぞれ垂直 $x$, 水平 $y$ 方向速度, $\rho$ は塩水密 度, $p$ は塩水圧力, $\nu$ は塩水動粘度, $\gamma$ は濃度変化による体膨張係 数, $g$ は重力加速度, $c$ は塩水濃度, $D$ は物質拡散係数であり, 添 字 0 は周囲塩水を表す。

流路入口で周囲塩水の流入速度は一様とし, 流入に伴う静圧か ら動圧への圧力変換および逆浸透膜内の溶質透過に関して拡散に よるもののみを考慮すると(Appendix 1 参照), 境界条件は,

$$
\begin{aligned}
& x=0, \quad 0<y<b ; \quad u=\left(u_{\mathrm{m}}\right)_{x=0}, \quad v=0, \quad c=c_{0} \\
& y=0, \quad x \geqq 0 ; \quad u=0, \quad v=v_{\mathrm{w}}, \\
& \psi\left(c_{\mathrm{w}}-c^{*}\right)+c_{\mathrm{w}} v_{\mathrm{w}}=D(\partial c / \partial y)_{\mathrm{w}} \\
& y=b, \quad x \geqq 0 ; \quad u=0, \quad v=0, \quad \partial c / \partial y=0 \\
& x=0 ; \quad p-p_{0}=-\rho\left(u_{\mathrm{m}}\right)_{x=0}{ }^{2} / 2 \\
& x=l ; \quad p-p_{0}=0
\end{aligned}
$$

ここで, $\left(u_{\mathrm{m}}\right)_{x=0}$ は流路入口 $(x=0)$ での $x$ 方向平均速度, $\psi$ は溶 質透過係数, $c^{*}$ は透過淡水濃度であり, 添字 $w$ は膜面 $(y=0)$ を 表す.

Eq. (5) 中において, 未知変数である膜面における $y$ 方向速度 $v_{\mathrm{w}}$ 


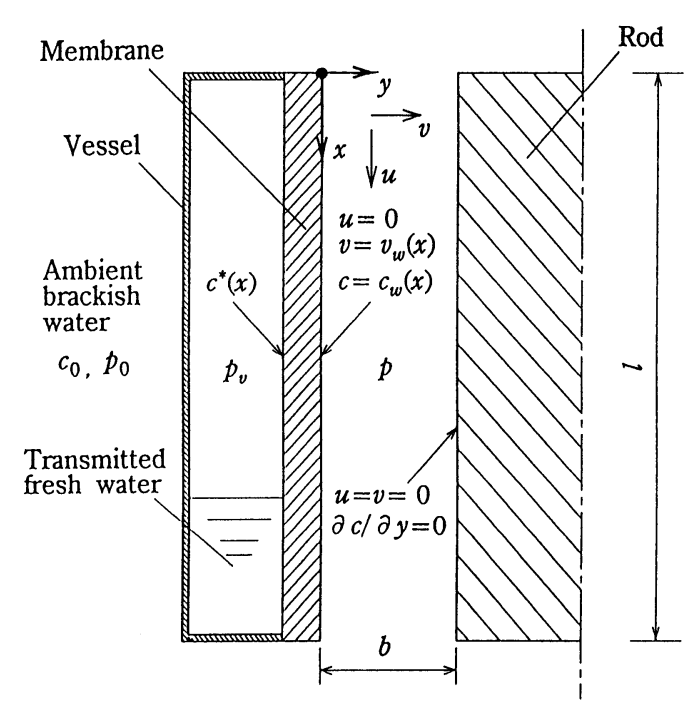

Fig. 1 Analytical system and coordinates

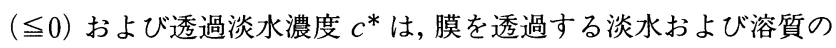
質量収支から導ける次式の関係 (Appendix 2 参照) から定まる.

$$
\begin{aligned}
& \rho_{\mathrm{w}} v_{\mathrm{w}}=-\phi \rho^{\circ}\left\{\rho g \delta-\left(c_{\mathrm{w}}-c^{*}\right)\left(\pi_{0} / c_{0}\right)\right\}-\phi\left(c_{\mathrm{w}}-c^{*}\right) \\
& c^{*}=\frac{\phi \rho^{*}\left(c_{\mathrm{W}}-c^{*}\right)}{\phi \rho^{\circ}\left\{\rho g \delta-\left(c_{\mathrm{w}}-c^{*}\right)\left(\pi_{0} / c_{0}\right)\right\}+\phi\left(c_{\mathrm{w}}-c^{*}\right)}
\end{aligned}
$$

ここで, $\phi$ は純水透過係数, $\delta$ は懸垂深さ, $\pi_{0}$ は周囲塩水濃度 $c_{0}$ に対応する浸透圧, $\rho^{\circ}$ は純水密度, $\rho^{*}$ は透過淡水密度である.な お, Eq. (10)は $c^{*}$ に関して 2 次方程式となっており， $c^{*}$ をその根 として表示することもできる.

また, $x$ 方向の平均速度 $u_{\mathrm{m}}$ および塩水平均濃度 $c_{\mathrm{m}}$ は, 流路入 口から任意の垂直方向距離まで $(x=0 \sim x)$ の流路域における次 式の巨視的物質収支式に制約されて， $x$ 方向に変化する.

$$
\begin{aligned}
& u_{\mathrm{m}} b=\int_{0}^{b} u d y=\left(u_{\mathrm{m}}\right)_{x=0} b+\int_{0}^{x} v_{\mathrm{w}} d x \\
& c_{\mathrm{m}} u_{\mathrm{m}} b=\int_{0}^{b} c u d y=c_{0}\left(u_{\mathrm{m}}\right)_{x=0} b-\int_{0}^{x} \psi\left(c_{\mathrm{w}}-c^{*}\right) d x
\end{aligned}
$$

さらに, 長さ $l$ の流路全域における透過淡水平均濃度 $\bar{c}^{*} お よ$ び膜単位幅当たりの純水透過流量 $q^{\circ}$ は (Appendix 3 参照),

$$
\begin{aligned}
& \bar{c}^{*}=\int_{0}^{l} \psi\left(c_{\mathrm{w}}-c^{*}\right) d x / \int_{0}^{l} \psi\left(c_{\mathrm{w}}-c^{*}\right) / c^{*} d x \\
& q^{\circ}=\int_{0}^{l} \phi\left\{\rho g \delta-\left(c_{\mathrm{w}}-c^{*}\right)\left(\pi_{0} / c_{0}\right)\right\} d x
\end{aligned}
$$

以上の各式を無次元化するために, 無次元量群,

$$
\begin{array}{ll}
U=\frac{b u}{\nu \Gamma}, & V=\frac{b v}{\nu}, \quad C=\frac{c}{c_{0}}, \quad P=\frac{b^{2}\left(p-p_{0}\right)}{\rho \nu^{2} \Gamma^{2}}, \\
X=\frac{x}{b \Gamma}, & Y=\frac{y}{b}, \quad L=\frac{l}{b \Gamma}, \quad \Delta=\frac{\rho g \delta}{\pi_{0}}, \\
\Phi=\frac{\rho g \delta b \phi}{\nu}, & \Psi=\frac{b \phi}{\nu}, \quad S c=\frac{\nu}{D}, \quad Q=\frac{b u_{\mathrm{m}}}{\nu \Gamma} \\
Q^{\circ}=\frac{q^{\circ}}{\nu \Gamma}, & C^{*}=\frac{c^{*}}{c_{0}}, \quad \bar{C}^{*}=\frac{\bar{c}^{*}}{c_{0}}, \quad \Gamma=\frac{b^{3} g c_{0} \gamma}{\nu^{2}}
\end{array}
$$

を導入すると，基礎方程式 Eqs. (1)〜 (3)，境界条件 Eqs. (4) ～(8)，境界条件に対する制約条件 Eqs. (9)，(10)，巨視的物質収 支式 Eqs. (11), (12), 透過淡水平均濃度 Eq. (13), および純水透過 流量 Eq. (14)はそれぞれ次式で表される.

$$
\begin{aligned}
& \frac{\partial U}{\partial X}+\frac{\partial V}{\partial Y}=0 \\
& U \frac{\partial U}{\partial X}+V \frac{\partial U}{\partial Y}=-\frac{d P}{d X}+\frac{\partial^{2} U}{\partial Y^{2}}+(C-1)
\end{aligned}
$$

$$
\begin{aligned}
& U \frac{\partial C}{\partial X}+V \frac{\partial C}{\partial Y}=\frac{1}{S c} \frac{\partial^{2} C}{\partial Y^{2}} \\
& X=0, \quad 0<Y<1 ; \quad U=(Q)_{X=0}, \quad V=0, \quad C=1 \\
& Y=0, \quad X \geqq 0 ; \quad U=0, \quad V=V_{\mathrm{w}}, \\
& \Psi\left(C_{\mathrm{w}}-C^{*}\right)+C_{\mathrm{w}} V_{\mathrm{w}}=(1 / S c)(\partial C / \partial Y)_{\mathrm{w}} \\
& Y=1, \quad X \geqq 0 ; \quad U=0, \quad V=0, \quad(\partial C / \partial Y)=0 \\
& X=0 ; \quad P=-(Q)_{X=0}^{2} / 2 \\
& X=L ; \quad P=0 \\
& V_{\mathrm{w}}=-\Phi\left\{1-\left(C_{\mathrm{w}}-C^{*}\right) / \Delta\right\}\left(\rho^{\circ} / \rho_{\mathrm{w}}\right)-\Psi\left(C_{\mathrm{w}}-C^{*}\right)\left(c_{0} / \rho_{\mathrm{w}}\right) \\
& C^{*}=\frac{{ }^{2}}{\Phi\left\{1-\left(C_{\mathrm{w}}-C^{*}\right) / \Delta\right\}\left(\rho^{\circ} / \rho^{*}\right)+\Psi\left(C_{\mathrm{w}}-C^{*}\right)\left(C_{0} / \rho^{*}\right)} \\
& Q=\int_{0}^{1} U d Y=(Q)_{X=0}+\int_{0}^{X} V_{\mathrm{w}} d X \\
& C_{\mathrm{m}} Q=\int_{0}^{1} C U d Y=C_{0}(Q)_{X=0}-\int_{0}^{X} \Psi\left(C_{\mathrm{w}}-C^{*}\right) d X(27) \\
& \bar{C}^{*}=\int_{0}^{L} \Psi\left(C_{\mathrm{w}}-C^{*}\right) d X / \int_{0}^{L} \Psi\left(C_{\mathrm{w}}-C^{*}\right) / C^{*} d X \\
& Q^{\circ}=\int_{0}^{L} \Phi\left\{1-\left(C_{\mathrm{w}}-C^{*}\right) / \Delta\right\} d X
\end{aligned}
$$

\section{2. 数值解析法}

本来, 無次元流路長さ $L$ が与えられると, 流路入口での無次元 誘起流量 $(Q)_{X=0}$ が定まる. しかし, 本数值解析では逆に $(Q)_{X=0}$ を与え, Eq. (23)に示したように, 流路内圧力と周囲圧力が等しく なる $P=0$ の位置を流路出口 $X=L$ と定める.

したがって, 本解析系のパラメーターは, 上述の $(Q)_{X=0}$ または $L$ のほか, 無次元懸垂深さ $\Delta$, 無次元純水透過係数 $\Phi$, 無次元溶 質透過係数 $\Psi$ ，およびシュミット数 $S c$ となる.

解析手順は, 溶質透過を無視した前報 (Miyatake et al., 1997) に示したものと基本的に変わりがなく, 基礎方程式 Eqs. (16) 〜（18）を差分化し, 境界条件 Eqs. (19)〜 (23)のもとで, 陰解法に より前進的に $X$ の各レベルで反復しつつ遂行し, 制約条件 Eqs. (24)，(25）を満足する各レベルの速度 $U, V$, 濃度 $C, C^{*}$, およ U゙圧力 $P$ の収束解を求め, Eq. (28) から無次元透過淡水平均濃度 $\bar{C}^{*}$ を, Eq. (29) から無次元純水透過流量 $Q^{\circ}$ を算出した.

計算は, 懸垂深さ, 逆浸透膜の純水透過係数 $\left(\phi=10^{-13} \sim 2 \times\right.$ $\left.10^{-12} \mathrm{~m}^{3} /\left(\mathrm{m}^{2} \cdot \mathrm{s} \cdot \mathrm{Pa}\right)\right)$, 溶質透過係数 $\left(\psi=5 \times 10^{-12} \sim 10^{-7} \mathrm{~m} / \mathrm{s}\right)$, お よび塩水物性值を考慮し, $\Delta=1.5 \sim 2.5, \Phi=10^{-3} \sim 10^{-2}, \Psi=10^{-8}$ $\sim 10^{-4}$, および $S c=10^{3} \sim 3 \times 10^{3}$ の範囲について行った. また, $(Q)_{X=0}$ は収束解が得られる可能な範囲に変えた。

\section{3. 数值解析結果}

\section{1 流路内の速度, 濃度, および圧カ}

無次元速度 $U, V$ および無次元濃度 $C$ が垂直 $X$ 方向に変化 する様子の代表例を Fig. 2 に示す. 流路入口近傍では， $U$ は一様 分布から放物線分布へ移行し始め, それに伴って $V$ は左右に大 きな正負のピークをもつ分布となる．海水が流路を流下していく と, 膜面側の $C$ の上昇によって膜面近傍の自然対流が促進される ので, $U$ の分布は膜面側へ若干片寄る. 無次元溶質透過係数 $\Psi$ が 大きくなるにつれ, 純水透過量が多くなる $(3.2,3.3$ 参照)ので, $U$ は小さくなり，それに伴って $C$ は上昇する.

流路内の無次元圧力 $P$ が垂直 $X$ 方向に変化する様子の代表例 をFig. 3 に示す. 流路入口近傍では, 塩水濃度は低く, まだ十分 

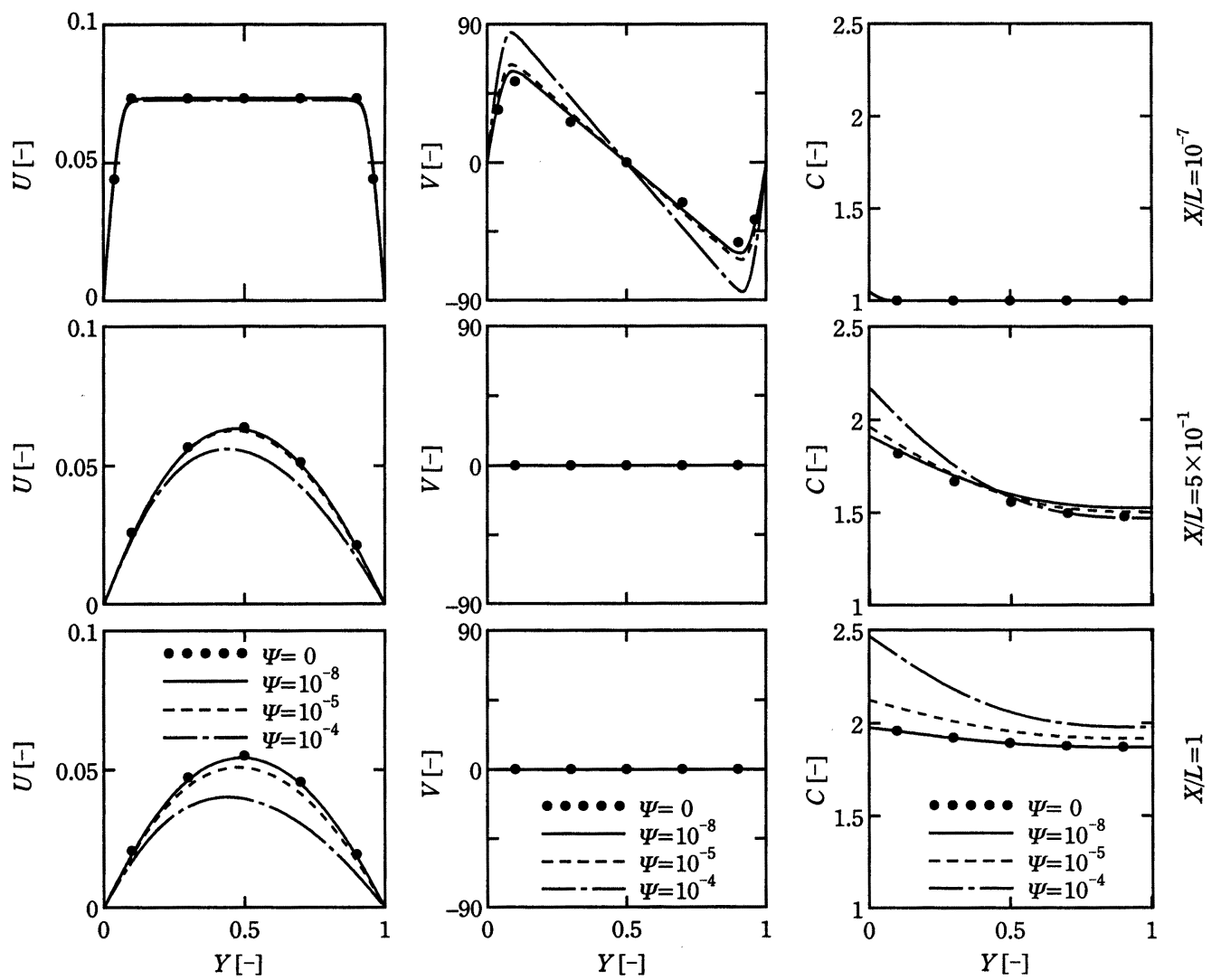

$\Delta=2.0, \Phi=5 \times 10^{-3}, S c=2 \times 10^{3},(Q)_{X=0}=7 \times 10^{-2}$

Fig. 2 Axial variation of dimensionless velocity and solute concentration profiles in channel

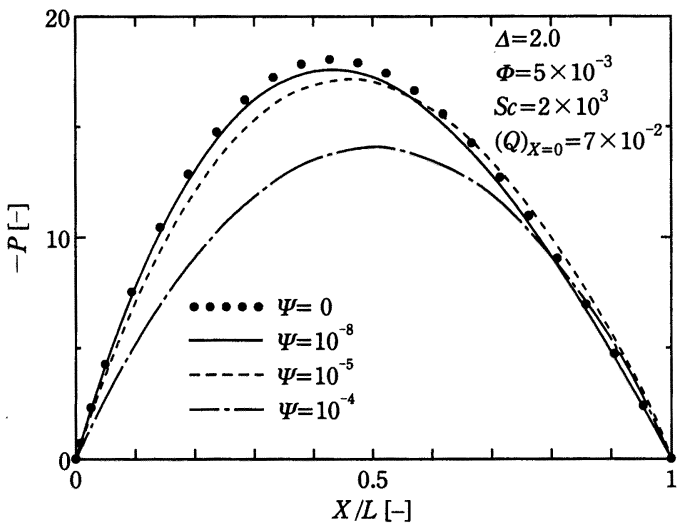

Fig. 3 Axial variation of dimensionless pressure in channel

な逆浮力が㗢かないので，所定の流量 $(Q)_{X=0}$ が流れるためには， 壁面摩擦に抗して塩水を流路内に吸い込む圧力降下が必要であり, $P$ は負の值となる。この圧力降下は濃度が上昇して逆浮力が大き くなる流路下流域で回復され, 流路出口で $P=0$ となる. 無次元溶 質透過係数 $\Psi$ が大きくなるにつれ, 所定の $(Q)_{X=0}$ を誘起するの に必要な無次元流路長さ $L$ が短くなる（Figs. 4, 5 参照）ので, 圧力降下は小さくなるとともに, 圧力降下域と圧力回復域の長さ に差がなくなり，放物線分布に近づく，なお， $(Q)_{X=0}$ がより増大 した場合には対応する $L$ が長くなり, 逆浮力が働く圧力回復域が 相対的に長くなっていく.

\section{2 誘起流量, 膜面の速度, および膜両面の浪度}

流路入口での無次元誘起流量 $(Q)_{X=0}$ と無次元量 $S c / L$ の関係 の代表例を Fig. 4 に示す. 無次元流路長さ $L$ および無次元溶質 透過係数 $\Psi$ が大きくなるにつれ, 流路内の塩水濃度は上昇して

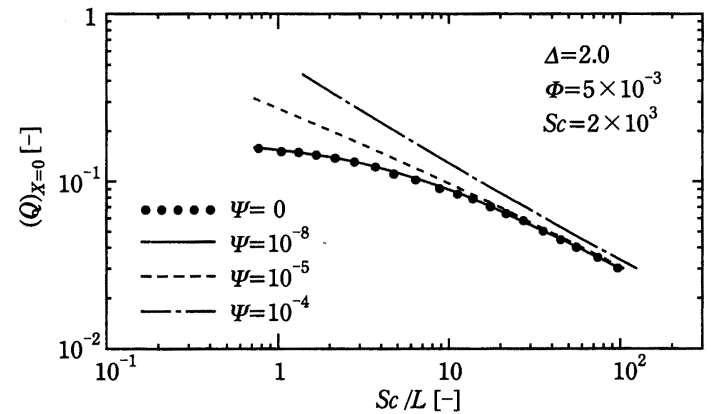

Fig. 4 Dimensionless induced flow rate at the entrance of channel

自然対流が促進されるので, $(Q)_{x=0}$ は増大する.

$\Psi=0$ の場合には, $L \rightarrow \infty(S c / L \rightarrow 0)$ において,

$$
(Q)_{X=0}=(1 / 12) \Delta(\Delta-1)
$$

の一定值に漸近する (Miyatake et al., 1997)が， $\Psi$ が大きくなる につれ，しだいに漸近傾向が現れなくなる.

膜面における $Y$ 方向無次元速度 $V_{\mathrm{w}}(\leqq 0)$ および膜両面におけ る塩水濃度 $C_{\mathrm{w}}$ と透過淡水濃度 $C^{*}$, ならびにそれらの濃度差 $C_{\mathrm{w}}-C^{*}$ が垂直 $X$ 方向に変化する様子の代表例を Fig. 5 に示す. 図中の○印は, 流路出口 $(X=L)$ での值を示す. 無次元溶質透過 係数 $\Psi$ が大きくなるにつれ, $-V_{\mathrm{w}}, C_{\mathrm{w}}, C^{*}$ はいずれも上昇する が， $C_{\mathrm{w}}-C^{*}$ は逆に低下する。これらの事柄は連鎖して生じてお $\eta$ ，直鎖的に説明できないが， $\Psi$ が大きくなると，まず，溶質透 過量が増大寸ることによって $C^{*}$ が上昇し, Eq. (24)の右辺第 1 項 の淡水透過の寄与は第 2 項の溶質透過の寄与に比べて大きいの で, 一 $V_{\mathrm{w}}$ を大きくさせる作用を及ぼす，それに伴って，膜面へ運 ばれる溶質量が多くなるので， $C_{\mathrm{w}}$ および $C^{*}$ は $X$ 方向により急 


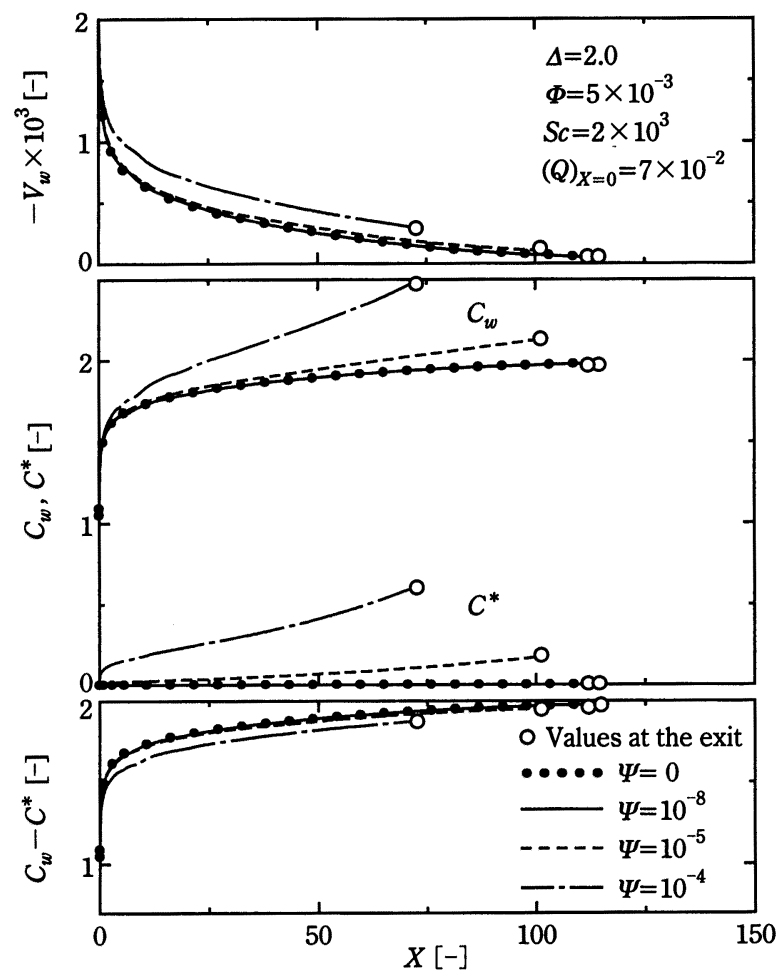

Fig. 5 Axial variation of dimensionless horizontal velocity and solute concentration at the membrane wall in channel, and dimensionless solute concentration of transmitted fresh water

速に上昇する，しかし， $\Psi$ が大きくなることによる $C^{*}$ の上昇 は，当然のことながら， $C_{\mathrm{w}}$ の上昇に比べて相対的に大きいので, それらの差 $C_{\mathrm{w}}-C^{*}$ は低下し, Eq. (24)の関係からー $V_{\mathrm{w}}$ は増加し た状態を維持することによりもたらされた結果である.

$\Psi=0$, すなわち $C^{*}=0$ の場合には, 無次元流路長さ $L$ が長く なって $C_{\mathrm{w}}=\Delta$ に達すると, Eq. (24)の関係から $V_{\mathrm{w}}=0$ となるの で, $C_{\mathrm{w}}>\Delta$ となることはないが, $\Psi>0$ の場合には $C_{\mathrm{w}}>\Delta$ となり うることが特徴である.

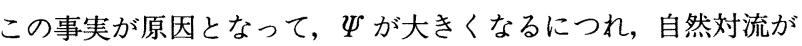
促進され， $(Q)_{\mathrm{x}=0}$ は増大するとともに, 所定の $(Q)_{\mathrm{x}=0}$ を誘起す るのに必要な無次元流路長さ $L$ が短くなるという前掲 Fig. 4 の 結果をもたらす。

\section{3 透過淡水平均漕度および純水透過流量}

流路全域における透過淡水平均濃度 $\bar{C}^{*}$ と無次元流路長さ $L$ の関係を Fig. 6 に示す. L が長くなると, 塩水濃度が上昇するの で, $\bar{C}^{*}$ は上昇する. 無次元懸垂深さ $\Delta$ が深くなると, Eq. (28)の 分子の溶質透過量が分母の淡水透過量に比べて相対的に減少し, $\bar{C}^{*}$ は低下する*. 無次元純水透過係数 $\Phi$ が小さくなるにつれ, 無 次元溶質透過係数 $\Psi$ が大きくなるにつれ, 溶質透過量が淡水透 過量に比べて相対的に増大するので, $\bar{C}^{*}$ は上昇する. $\Psi=0$ の場 合に常に $\bar{C}^{*}=0$ となる。 また，シュミット数 $S c$ が大きくなる と, 膜面から塩水流バルクへの溶質の拡散が抑制され, 濃度分極 が大きく現れるので, 膜面における無次元濃度 $C_{\mathrm{w}}$ が上昇し, それ に伴い $\bar{C}^{*}$ も上昇する.

許容される $\bar{C}^{*}$ の值は原水の塩水濃度によって定まるが, 原水

* 陸上用逆浸透法海水淡水化装置においても, 操作圧力を上昇させると, 純水透過量が溶質透過量に比べ相対的に増大し, 透過淡水濃度が低下 して良質の淡水が得られることは周知の事実である.
が海水で透過淡水を地上水とブレンドしない場合には, 蒸発残留 物に関する水道水基準の值 $(500 \mathrm{mg} / \mathrm{l}$ 以下) と海水の值 $(35,000$ $\mathrm{mg} / \mathrm{l})$ の比 $\bar{C}^{*}<1.4 \times 10^{-2}$ の条件を満たすように, Fig. 6 を用い てシステムの設計と操作を行う必要がある.

無次元純水透過流量 $Q^{\circ}$ (無次元淡水透過流量とみなせる**) と 無次元量 $S c / L$ の関係を Fig. 7 に示す. 無次元流路長さ $L$ が長 くなるほど, 無次元懸垂梁さ $\Delta$ が深くなるほど, 無次元純水透過 係数 $\Phi$ が大きくなるほど, 当然の結果として, $Q^{\circ}$ は增大する. 無 次元溶質透過係数 $\Psi$ が大きくなると, Fig. 5 で示した様に, 膜両 面における塩水と透過淡水の濃度差 $C_{\mathrm{w}}-\mathrm{C}^{*}$ が低下するので, Eq. (29) の関係から， $Q^{\circ}$ は増大する.

シュミット数 $S c$ の影響については，横軸を $S c / L$ にとってい る***ので，図上で瞬時に見分けられないが，Sc が大きくなるほ ぞ, 濃度分極がより大きく現れるので， $Q^{\circ}$ は減少している.

$\Psi=0$ の場合には, $L \rightarrow \infty(S c / L \rightarrow 0)$ において,

$Q^{\circ}=(1 / 12)(1.012+0.012 \Delta)(\Delta-1)^{2}$

の一定值に漸近する (Miyatake et al., 1997) が, $\Psi$ が大きくなる につれ，しだいに漸近傾向が現れなくなるのは前掲 Fig. 4 の $(Q)_{X=0}$ の傾向と同様である.

以上の結果から， $\Delta$ を深くし， 大させ, $\bar{C}^{*}$ を低下させるので, 推奨される方法であることがわか る.一方， $L$ を長くし， $\Psi$ を大きくすることは， $Q^{\circ}$ を増大させる ものの， $\bar{C}^{*}$ を昇させるので，好ましい方法とはいえない．な お，Sc は塩水の物性值なので, 選択の余地はない.

\section{結言}

静圧頭を利用する逆浸透法塩水脱塩システムに関して, 膜の溶 質透過を考虑した場合について，逆浸透膜面と非透過性面からな る塩水流路内で，濃度差に基づいて誘起される層流自然対流場の 速度, 濃度, および圧力, ならびに淡水透過速度および透過淡水 濃度について数值解析した。 その結果から, 流路長さ, 懸垂梁さ, 純水透過係数，および溶質透過係数を大きくすることは，いずれ も取得淡水量を増大させること, これらのうち，流路長さおよび 溶質透過係数を大きくすると, 取得淡水濃度が上昇するという障 害を伴うが, 懸垂深さおよび純水透過係数を大きくすると, 取得 淡水濃度が低下するという好ましい効果も伴うこと, などを定量 的に明らかにした。

\section{Appendix 1 逆漫透膜内の溶質透過}

逆浸透膜内においては, 拡散による溶質透過のほか, 純水透過に伴 j溶質透過も生ずる.この場合, 膜面積基準の淡水透過速度 $v^{*}(\geqq 0)$ は (Spiegler and Kedem, 1966),

$$
v^{*}=\frac{\psi}{1-\sigma} \ln \left\{\frac{\sigma(1-R)}{\sigma-R}\right\} \quad(\sigma=\sigma)
$$

ここで, $\phi$ は溶質透過係数, $\sigma$ は反射係数, $R$ は塩阻止率である.

** 透過純水と透過淡水の密度の相違は, 飲料用に適する蒸発残留物の 最大値 $500 \mathrm{mg} / l$ においても $0.03 \%$, 海水の蒸発残留物 35,000 $\mathrm{mg} / l$ においても $2.4 \%$ なので, 両者の体積は十分等しいとみなせ る.

*** Figs. 4, 7 において, 横軸に $S c / L$ をとる理由は, $(Q)_{X=0}$ および $Q^{\circ}$ と $S c / L$ の関係が, 特に $\Psi=0$ の場合, $S c$ にほとんど影響されない ためである。このことは, 対応した系内の温度差に基づく自然対流 に関する解析結果(Miyatake and Fujii, 1972；1973)において, 誘 起流量およびヌセルト数と（プラントル数 $/ L)$ の関係が, プラント ル数にほとんど影響されないのと同様である. 

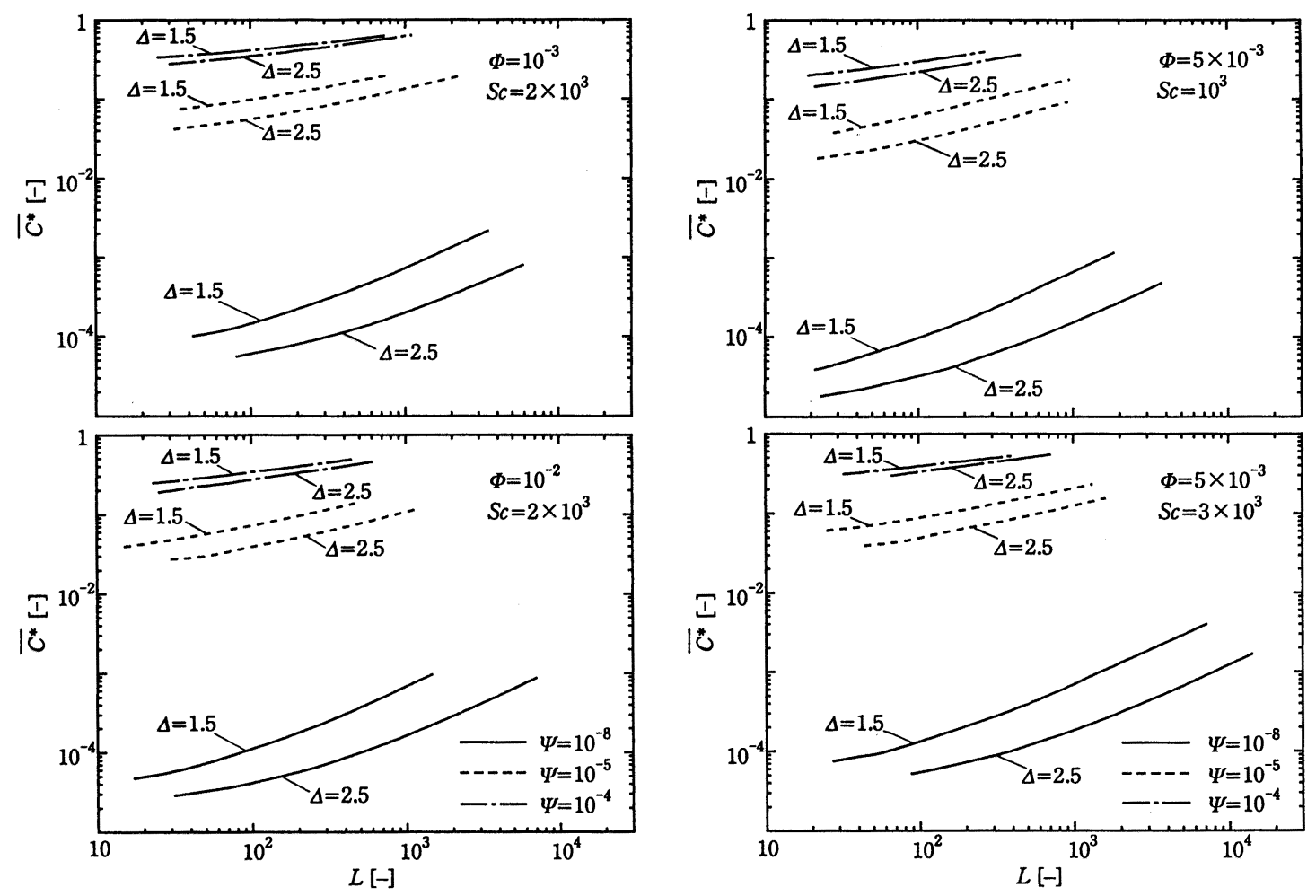

Fig. 6 Dimensionless mean solute concentration of transmitted fresh water
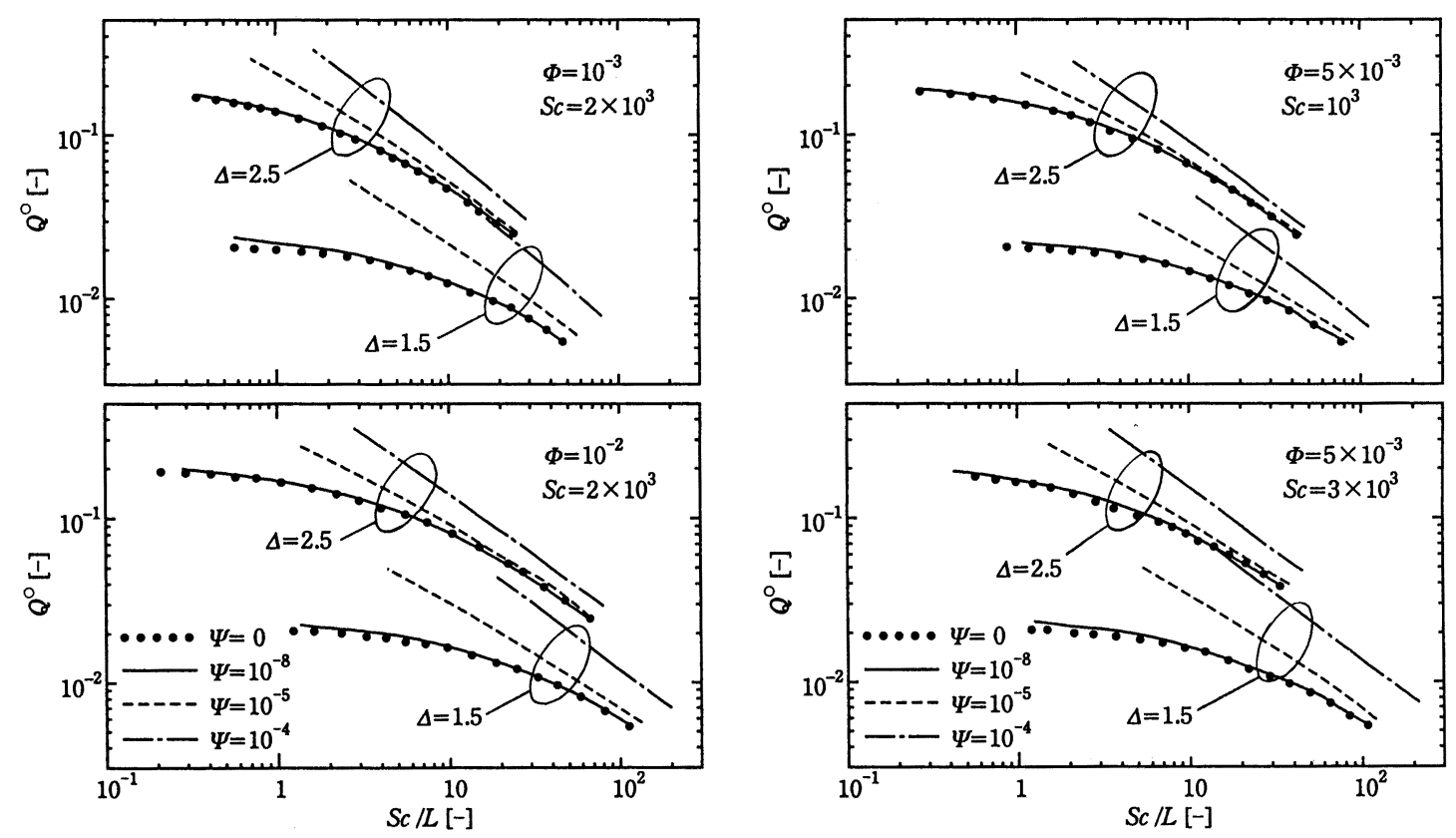

Fig. 7 Dimensionless flow rate of transmitted pure water (which is considered to be that of transmitted fresh water)

拡散による溶質透過のみが生ずる場合 $(\sigma=1)$ は, Eq. (A 1)で $\sigma=$ 1 の極限をとると,

$$
v^{*}=\phi R /(1-R) \quad(\sigma=1)
$$

両者の場合で, $R$ は若干異なるが, Eq. (A 2)と Eq. (A 1)の比が 5 $\%$ 以内で一致する条件,

$$
\frac{R(1-\sigma)}{1-R}\left[\ln \left\{\frac{\sigma(1-R)}{\sigma-R}\right\}\right]^{-1}>0.95
$$

が満たされれば, 拡散による溶質透過に比べ, 純水透過に伴う溶質透 過は無視できるとみなせる．ちなみに $R=0.8 ， 0.9$ のそれぞれに対 し $\sigma>0.983 ， 0.991$ となる.

溶質透過が比較的大きい膜においても $\sigma=0.998$ という測定値が
あり (Nakao, 1996), 実用に供される逆浸透膜の反射係数は 1 に極め て近いことから, 拡散による溶質透過のみを考慮して, 輸送方程式を たてる場合が多い(Oya, 1976； Kumano and Ukai, 1990).

\section{Appendix 2 Eqs.(9),(10)の導出}

淡水容器内圧力を $p_{\mathrm{v}}$ (Fig. 1 参照), 透過淡水濃度 $c^{*}$ に対応する浸 透圧を $\pi^{*}$ とすると, 膜表面積基準の純水透過速度 $v^{\circ}(\geqq 0)$ は (Kimura and Nakao, 1990 ; Kumano and Ukai, 1990),

$$
v^{\circ}=\phi\left\{\left(p-p_{\mathrm{v}}\right)-\left(\pi_{\mathrm{w}}-\pi^{*}\right)\right\}
$$

懸垂深巳 $500 \mathrm{~m}$ 程度の塩水中において, 流路内塩水圧力 $p$ と周囲 塩水圧力 $p_{0}(=\rho g \delta+$ 大気圧 $)$ の差異は $1 \%$ 以下で, ともに大気圧の 
50 倍のオーダーの同じ值をもつとみなせる. 容器半分まで淡水が貯 まったとしても， p、は初気圧（大気圧）の 2 倍程度なので,

$$
p-p_{\mathrm{v}} \fallingdotseq \rho g \delta
$$

透過淡水を含め塩水の浸透圧 $\pi$ はその濃度 $c$ にほぼ比例する (Oya, 1976)ので,

$$
\begin{aligned}
& \pi_{\mathrm{w}}=\left(c_{\mathrm{w}} / c_{0}\right) \pi_{0}, \quad \pi^{*}=\left(c^{*} / c_{0}\right) \pi_{0} \\
& \text { Eqs. }(\mathrm{A} 4) \sim(\mathrm{A} 6) \text { から, } \\
& v^{\circ}=\phi\left\{\rho g \delta-\left(c_{\mathrm{w}}-c^{*}\right)\left(\pi_{0} / c_{0}\right)\right\}
\end{aligned}
$$

膜単位面積当たりの溶質透過質量流量, すなわち膜表面積基準の 淡水透過速度 $v^{*}(\geqq 0)$ と $c^{*}$ の積は (Oya, 1976; Kumano and Ukai, 1990),

$$
c^{*} v^{*}=\psi\left(c_{\mathrm{w}}-c^{*}\right)
$$

したがって, 膜単位面積当たりの淡水透過質量流量, すなわち $v^{*}$ $(\geqq 0)$ と $\rho^{*}$ の積は,

$$
\rho^{*} v^{*}=-\rho_{\mathrm{w}} v_{\mathrm{w}}=\rho^{\circ} v^{\circ}+c^{*} v^{*}=\rho^{\circ} v^{\circ}+\psi\left(c_{\mathrm{w}}-c^{*}\right)
$$

Eqs. (A 8), (A 9)の関係から, 透過淡水濃度 $c^{*}$ は,

$$
c^{*}=\frac{\psi\left(c_{\mathrm{w}}-c^{*}\right)}{v^{*}}=\frac{\rho^{*} \psi\left(c_{\mathrm{w}}-c^{*}\right)}{\left\{\rho^{\circ} v^{\circ}+\psi\left(c_{\mathrm{w}}-c^{*}\right)\right\}}
$$

Eq. (A 7)を Eq. (A 9)，Eq. (A 10)に代入すると，それぞれ Eq. (9)， Eq. (10)が得られる.

\section{Appendix 3 Eqs.(13),(14)の導出}

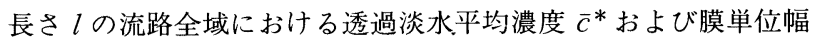
当たりの純水透過流量 $q^{\circ}$ は,

$$
\begin{aligned}
& \bar{c}^{*}=\int_{0}^{l} c^{*} v^{*} d x / \int_{0}^{l} v^{*} d x \\
& q^{\circ}=\int_{0}^{l} v^{\circ} d x
\end{aligned}
$$

Eq. (A 8)を Eq. (A 11)に代入すると, Eq. (13)が得られ, Eq. (A 7) を Eq. (A 12)に代入すると，Eq.(14)が得られる.

[謝辞] 本研究はソルトサイエンス研究財団および文部省科学研 究費基盤研究 (課題番号 07555239)の助成を受けて行った. 記して謝意を表 する.

\section{Nomenclature}

$b \quad=$ distance between parallel plates

$C=$ dimensionless solute concentration of brackish water defined by Eq. (15) [-

$C^{*}=$ dimensionless solute concentration of transmitted fresh water defined by Eq. (15) [-]

$\bar{C}^{*}=$ dimensionless mean solute concentration of transmitted fresh water defined by Eq. (15)

$c=$ solute concentration of brackish water $\quad\left[\mathrm{kg} / \mathrm{m}^{3}\right]$

$c^{*}=$ solute concentration of transmitted fresh water $\left[\mathrm{kg} / \mathrm{m}^{3}\right]$

$\bar{c}^{*}=$ mean solute concentration of transmitted fresh water

$\left[\mathrm{kg} / \mathrm{m}^{3}\right]$

$D=$ mass diffusivity of solute in water $\quad\left[\mathrm{m}^{2} / \mathrm{s}\right]$

$g=$ gravitational acceleration $\quad\left[\mathrm{m} / \mathrm{s}^{2}\right]$

$L=$ dimensionless length of parallel plate channel defined by Eq. (15)

$l \quad=$ length of parallel plate channel

$P=$ dimensionless pressure in brackish water defined by Eq. (15)

$p \quad=$ pressure in brackish water

$p_{\mathrm{v}}=$ pressure in transmitted fresh water vessel

$Q=$ dimensionless induced flow rate between parallel plates defined by Eq. (15)

$Q^{\circ}=$ dimensionless flow rate of transmitted pure water defined by Eq. $(15)(\fallingdotseq$ dimensionless flow rate of transmitted fresh water)

$q^{\circ}=$ flow rate of transmitted pure water per unit width of membrane $\left[\mathrm{m}^{3} /(\mathrm{m} \cdot \mathrm{s})\right]$

$R=$ salt rejection $\left\{=\left(c_{\mathrm{w}}-c^{*}\right) / c_{\mathrm{w}}\right\}$

$S c=$ Schmidt number of brackish water defined by Eq. (15)

$U=$ dimensionless velocity in $X$-direction defined by Eq. (15)

$=$ velocity in $x$-direction $\quad[\mathrm{m} / \mathrm{s}]$

$V=$ dimensionless velocity in $Y$-direction defined by Eq. (15)

$=$ velocity in $y$-direction $\quad[\mathrm{m} / \mathrm{s}]$

$v^{*}=$ velocity of transmitting fresh water (based on the surface area of membrane) $[\mathrm{m} / \mathrm{s}]$

$v^{\circ}=$ velocity of transmitting pure water (based on the surface area of membrane) $[\mathrm{m} / \mathrm{s}]$

$X=$ dimensionless vertical coordinate defined by Eq.(15) [-]

$x=$ vertical coordinate [m]

$Y=$ dimensionless horizontal coordinate defined by Eq. (15)

$y=$ horizontal coordinate $[\mathrm{m}]$

$\Gamma=$ dimensionless concentration coefficient of volumetric expansion defined by Eq. (15) [-]

$\gamma=$ concentration coefficient of volumetric expansion

$\Delta=$ dimensionless submerged depth of device defined by Eq. (15) $\left[\mathrm{m}^{3} / \mathrm{kg}\right]$

= submerged depth of device

$\nu=$ kinematic viscosity of brackish water $\left[\mathrm{m}^{2} / \mathrm{s}\right]$

$\pi=$ osmotic pressure of brackish water $[\mathrm{Pa}]$

$\pi^{*}=$ osmotic pressure of transmitted fresh water $\quad[\mathrm{Pa}]$

$\rho=$ density of brackish water $\quad\left[\mathrm{kg} / \mathrm{m}^{3}\right]$

$\rho^{*}=$ density of transmitted fresh water $\quad\left[\mathrm{kg} / \mathrm{m}^{3}\right]$

$\rho^{\circ}=$ density of transmitted pure water $\quad\left[\mathrm{kg} / \mathrm{m}^{3}\right]$

$\sigma=$ refrection coefficient $[-]$

$\Phi=$ dimensionless pure water permeability of membrane defined by Eq. (15) [-]

$\phi=$ pure water permeability of membrane $\left[\mathrm{m}^{3} /\left(\mathrm{m}^{2} \cdot \mathrm{s} \cdot \mathrm{Pa}\right)\right]$

$\Psi=$ dimensionless solute permeability of membrane defined by Eq. (15)

$[-]$
$[\mathrm{m} / \mathrm{s}]$

$\psi=$ solute permeability of membrane

〈Subscripts〉

$\mathrm{m}=$ mean value

$\mathrm{w}=$ membrane wall

0 = ambient brackish water

\section{Literature cited}

Hayashi, M.; The Report on the Hybrid Compressed Air Energy Storage Combined with Reverse Osmosis Membrane Method, Nippon Gakujutsu Kyoryoku Zaidan (1997)

Kaiyoshuppan ed. ; “The Manned Deep-Sea Station," Kaiyo Monthly, 23, 349-473 (1991)

Kimura, H. and S. Nakao ; Maku Bunri Gijutsu Manual, Chap. 1, p. 9, IPC, Tokyo, Japan (1990)

Kumano, A. and T. Ukai ; Maku Bunri Gijutsu Manual, Chap. 2, p. 118, IPC, Tokyo, Japan (1990)

Miyatake, O., K. Tagawa, S. Takaki and H.Noda ; "Numerical Analysis for a Seawater Desalination System by Reverse Osmosis Utilizing the Static Pressure due to the Depth of the Sea," Kagaku Kogaku Ronbunshu, 23, 251-258 (1997) 
Miyatake, O. and T. Fujii ; "Free Convective Heat Transfer between Vertical Parallel Plates-One Plate is Isothermally Heated and the Other is Isothermally Insulated," Kagaku Kogaku, 36, 405-412 (1972) ; Heat Transfer Japanese Reserch, 1, 30-38 (1972)

Miyatake, O. and T. Fujii; "Natural Convective Heat Transfer between Vertical Parallel Plates with Unequal Uniform Temperatures," Kagaku Kogaku, 37, 491-496 (1973) ; Heat Transfer Japanese Reserch, 2, 79-88 (1973)

Nakao, S.; "Sea Water Desalination Process for High Recovery of
Fresh Water by Reverse Osmosis," Bull. Soc. Sea Water Science, Japan, 50, 406-412 (1996)

Oya, H. ; Gyakushintoho Gengairokaho Riron, p. 14, p.19, p. 238, Saiwai Shobo, Tokyo, Japan (1976)

Spiegler, K. S. and O. Kedem; "Thermodynamics of Hyperfiltration (Reverse Osmosis) : Criteria for Efficient Membranes," Desalination, 1, 311-326 (1966)

Water Re-use Promotion Center ; Internal Materials for Investigation (1997)

\title{
Effect of the Solute Permeation on a Reverse Osmosis Brackish Water Desalination System Utilizing the Static Pressure Head
}

\author{
OSAMU MIYATAKE and KOTARO TAGAWA
}

Department of Chemical Systems and Engineering, Graduate School of Engineering, Kyushu University, Fukuoka 812-8581

Key words: membrane separation, mass transfer, reverse osmosis, desalination, solute permeation, static pressure head, natural convection, numerical analysis.

To complement the authors' previous numerical analysis for a RO seawater desalination system utilizing the static pressure due to the depth of the sea, a numerical analysis is performed for a RO brackish water desalination system utilizing the static pressure head of brackish water in a vertical pit, by taking into consideration the solute permeation through membrane.

Numerical results are obtained for the effects of the length of channel, the submerged depth of device, the pure water permeability of membrane, the solute permeability of membrane, and the Schmidt number of brackish water on the axial variation of velocity, concentration, and pressure in laminar natural convection flow of brackish water, caused by the concentration difference in the moderately narrow annular channel formed between a tube-type membrane and a cylindrical rod. The effects on the axial variation of the velocity of transmitting fresh water and the concentration of transmitted fresh water are also examined.

From the results, it is shown quantitatively that the application of large submerged depth of device and the adoption of high pure water permeability of membrane bring about a increase in the flow rate of fresh water with low solute concentration. 